\title{
Procedures for Estimating Nuclear Fuel Cycle Costs
}

\author{
J. R. Young
}

March 1977

Prepared for the Energy Research and Development Administration under Contract EY-76-C- -10 - -1830 
This report was prepared as an account of work sponsored by the United States Government. Neither the United States nor the Energy Research and Development Administration, nor any of their employees, nor any of their contractors, subcontractors, or their employees, makes any warranty, express or implied, or assumes any legal liability or responsibility for the accuracy, completeness or usefulness of any information, apparatus, product or process disclosed, or represents that its use would not infringe privately owned rights.

P.ACIFIC NORTHWEST I.ABORATORY

operated by

BATTELLE

for the

ENERGY RESEARCH AND DEVELOPMENT ADMINISTRATION

Under Contract EY-76-C-06-1830

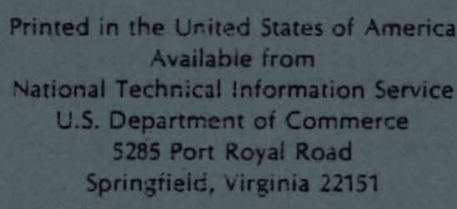

Price: Printed Cooy 5 *; Microfiche $\$ 3.00$

$\begin{array}{lc}\text {-Pages } & \text { Selling Price } \\ 001-025 & \$ 4.50 \\ 026-050 & \$ 5.00 \\ 051-075 & \$ 5.50 \\ 076-100 & \$ 6.00 \\ 101-125 & \$ 6.50 \\ 126-150 & \$ 7.00 \\ 151-175 & \$ 7.75 \\ 176-200 & \$ 8.50 \\ 201-225 & \$ 8.75 \\ 226-250 & \$ 9.00 \\ 251-275 & \$ 10.00 \\ 275-300 & \$ 10.25\end{array}$


PROCEDURES FOR ESTIMATING NUCLEAR FUEL CYCLE COSTS

by

J. R. Young

March 1977

BATTELLE

Pacific Northwest Laboratories

Richland, Washington 99352 
$\checkmark$

$\because$ 


\section{PREFACE}

The operation of nuclear fuel cycle facilities will introduce noxious materials, both radiological and chemical, into the environment through routine discharges of both liquid and airborne effluents. The environmental implications of continued development of existing nuclear fuel cycles and implementation of new fuel cycles must be determined systematically to assure the timely development and demonstration of technologies which control or eliminate the discharge of these materials.

To address this need for a comprehensive systems analysis of effluent control technologies for the nuclear fuel cycles, ERDA's Division of Environmental Control Technology has funded a program, Analys is of Nuclear Fuel Cycles, at Battelle, Pacific Northwest Laboratory (PNL). The objective of this program is to identify areas in developing nuclear fuel cycles (1) where environmental controls seem to be inadequate, (2) where inconsistencies and conflicts exist in environmental policy, and (3) where improved environmental controls can be justified on a cost/benefit basis (i.e., ensure that funds are not expended in cases where neither potential effects nor public concerns warrant such expenditures). The program initially focuses on current and "near future" LWR effluent control technology. Later work will focus on cost/benefit analyses of effluent control technologies for advanced LWR alternative fuel cycles and for LMFBR fuel cycles. Further work will concnetrate on analyzing other advanced nuclear energy systems (e.g., thorium, fusion) and integrating results from the various energy technology studies to evaluate the total status of environmental control technology for the nuclear industry.

The key elements in the program are:

- A computer code which permits calculation of mass balances of some 500 materials in a given fuel cycle as a function of time and projected electrical energy demand

- A cost analysis of each facility in a given fuel cycle (both capital and operating costs) 
- An environmental assessment analysis for each effluent in a given fuel cycle which compares calculated effluent rates with current and projected NRC and EPA standards

- An analysis which ties the above three elements into a single evaluation of effluent control technologies for a given fuel cycle.

The outputs of this program will be a series of reports which:

- Identify the effluents from and the control technologies for a series of nuclear fuel cycles

- Define problem areas where current effluent control technologies will not be adequate to meet existing or proposed effluent standards

- Evaluate alternative effluent control technologies for application to those nuclear fuel cycle effluents which were defined as having inadequate controls

- Recommend improvements in specific effluent control technologies, including new research and new applications of existing technology.

This report is one of approximately ten that will be published during the course of the program. The first three reports to be published describe the analytical tools used in the study. Since these analytical methodologies have applications far beyond the scope of this study, they deserve special attention, particularly by those engaged in environmental analyses and cost/benefit studies of environmental impacts. These documents are:

ENFORM: An ENergy InFORMation System, BNWL-2195, by C.M. Heeb, W.L. Purcell, and B.M. Cole.

Procedures for Estimating Nuclear Fuel Cycle Costs, BNWL-2210, by John Young.

Environmental Assessment Methodology for the Nuclear Fuel Cycle, BNWL-2219, by D.L. Brenchley, J.K. Soldat, J.A. McNeese and E.C. Watson.

The remaining reports will describe the nuclear fuel cycle facilities to be studied and the results of our analyses.

These reports are all available from the National Technical Information Service. 
$\therefore$

.

. 


\section{SUMMARY}

Standard procedures for estimating capital and operating costs for the Environmental Control Technology Project are presented in this report. Two different procedures were used for estimating capital costs: 1) general order-of-magnitude estimates for those facilities which are invariant among environmental control technologies, and 2) detailed estimating procedures for those facilities and control systems expected to vary among comparisons of environmental control methods.

The general approaches and procedures of NUS-531 ${ }^{1}$ were used for detailed capital cost estimates. Detailed procedures are presented for operating cost estimates. These include estimating worksheets and specific procedures for each of the components of the operating costs. These also were based on the approach of NUS-531.

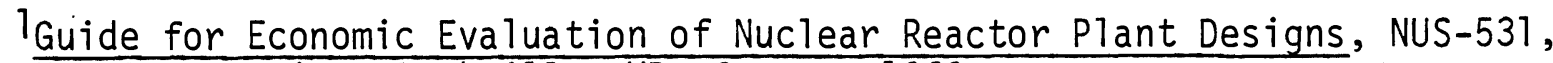
NUS Corporation, Rockville, MD, January 1969. 



\section{CONTENTS}

PREFACE . . . . . . . . . . . . . . . . . . . . . . .

SUMMARY . . . . . . . . . . . . . . . . . . . . . . . . . .

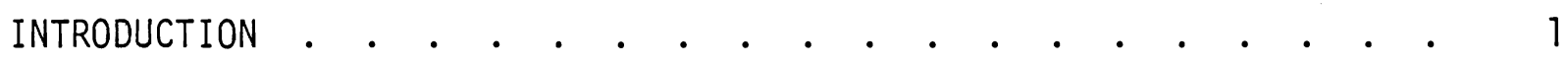

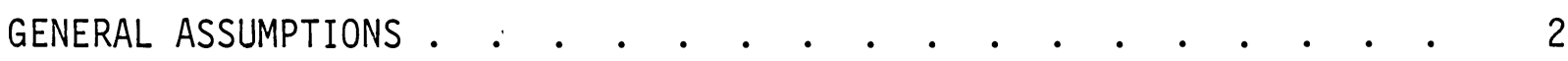

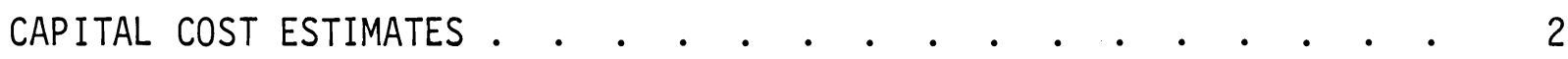

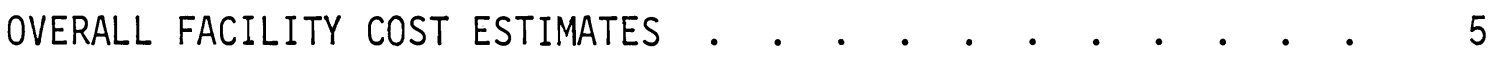

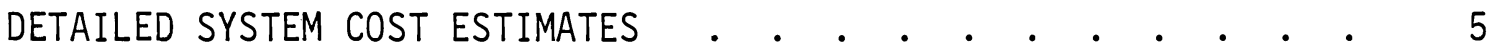

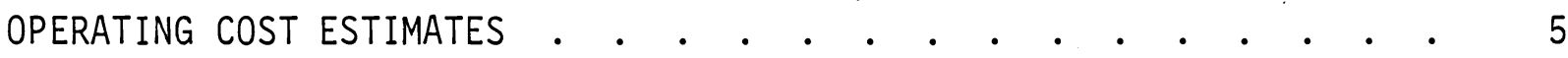

PERSONNEL COSTS • . . . . . . . . . . . . . . . . . 9

MISCELLANEOUS SUPPLIES AND EQUIPMENT

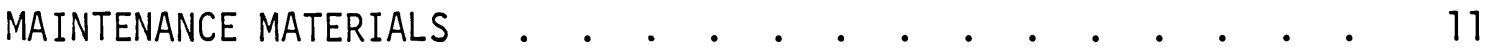

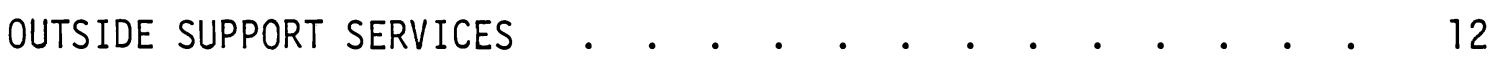

MISCELLANEOUS DIRECT COSTS . . . . . . . . . . . . . 12

GENERAL \& ADMINISTRATIVE COSTS . . . . . . . . . . . 12

PROCESS MATERIALS . . . . . . . . . . . . . . . . 13

UTILITY COSTS . . . . . . . . . . . . . . . . . . . . 13

OTHER COSTS . . . . . . . . . . . . . . . . . . . . . .

APPENDIX A - CAPITAL COST ESTIMATE DEFINITIONS . . . . . . . . A-1

APPENDIX B - COSTS OF TRUCK SHIPMENT OF NON-HIGH-LEVEL WASTE . . . B-1 
$\therefore$

$\cdot \cdot$

.

.

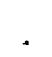


PROCEDURES FOR ESTIMATING NUCLEAR FUEL CYCLE COSTS

\section{INTRODUCTION}

The Environmental Control Technology (ECT) project has studied the fuel cycles for nuclear power plants to determine the state of the technology for controlling releases to the environment. Capital and operating cost estimates were prepared for each of the fuel cycle facilities and the related available methods for controlling releases. These cost estimates, plus information on environmental effects, were then used to compare alternative control systems. This comparison was to demonstrate the feasibility of defining the optimum sys tems.

The large number of cost estimates generated by this project and the many individuals making those estimates made it necessary to establish standard estimating procedures and assumptions to assure uniform and comparable results. This report describes the general approaches and assumptions adopted for preparing the environmental control technology cost estimates.

The report contains three main sections. The first section describes the general assumptions that apply to preparation of both capital and operating cost estimates. The second section describes the procedures for estimating capital costs, and the third describes those for estimating operating costs.

Assumptions specific to the Environmental Control Technology project are presented throughout this document. Many of those assumptions are unique to that project and should not be used for other studies unless analysis shows that they are applicable to those studies.

A1 1 cost estimates were based on the facility and environmental control system descriptions provided by other members of the ECT project teams. References to descriptions mean reference to the descriptions provided by those other members of the project. 


\section{GENERAL ASSUMPTIONS}

Preparation of the capital and the operating cost estimates was based on the following assumptions:

- All costs are based on mid-1976 dollar values. No cost escalation beyond 1976 is included.

- Facilities are expected to operate over a normal industrial life of 30 to 50 years.

- Facility characteristics are based on state-of-the-art technology in cases where similar facilities have been built and operated. In cases where new technology is needed, a minimum of extrapolation of technology to provide an economically viable design is assumed.

- Capital cost estimates include all costs normally included in such estimates, as described in NUS-531. (1)

- The general approaches and procedures of NUS-531 are used unless otherwise stated.

- All costs are based on a mature industry and generally represent duplicates of facilities previously built elsewhere.

\section{CAPITAL COST ESTIMATES}

The capital cost estimates were prepared by subcontractors on the basis of facility and system descriptions provided by Battelle, Pacific Northwest Laboratory (PNL). The subcontractors made two sets of cost estimates: a) overall facility unit cost estimates, and b) detailed system cost estimates. A set of general assumptions related specifically to capital cost estimates was used to assure that cost estimates be uniform and comparable. These are described in Table 1. 
TABLE 1. Bases and Methods for Estimating Capital Costs

\section{Construction Conditions}

As a basis for cost estimating, the construction conditions described below are assumed to prevail at a.11 sites.

Construction Labor will follow a 40-hr, single shift work week schedule except for casual overtime (e.g., to complete a concrete pour) and except in instances where two- or three-shift concrete work operations are planned in order to meet the construction schedule.

Severe Work Stoppages such as extensive jurisdictional disputes between labor crafts will not occur during construction.

Labor Availability in each craft will be adequate so that importing labor, except for general foreman, will not be required.

Craft Labor Wage Rates, including fringe benefits, are those prevailing in the geographic region of the construction site in mid-1976.

\section{Pricing: Field Costs}

Pricing for the various elements which comprise the field costs was done by the methods described below.

Major Equipment Costs were determined using estimated prices of similar equipment from other cost estimates of fuel reprocessing plants, radioactive wastes disposal processes, and other plants dealing with the nuclear fuel cycle. Necessary adjustments for capacity, pressure, temperature, complexity and metallurgy were made and adjusted prices were escalated to mid-1976. In the absence of design information, cost allowances were based on engineering judgment and recent nuclear experience.

Bulk Materials were determined either as a function of major equipment costs or as a cost allowance, except in instances where enough information existed to warrant quantity assessments and unit pricing of certain specifically identified materials.

Direct Labor costs were evaluated from estimated manhours for erection and installation sequences, from operations and craft wage rates, and from fringe benefits in effect at mid-1976. Labor manhours are representative of the craft production rates in the area of reference jobsites. 


\section{TABLE 1 (Cont'd)}

Indirect Site Construction Costs such as contractor's fee, supervision, construction equipment, tools and consumable supplies, temporary

facilities and utilities, material handling, cleanup and the like were combined and evaluated as a factor of the total direct labor.

Architect-Engineer (A-E) Services

The costs of A-E services are estimated as a percentage of the total field cost and include burden and fee.

Owner's Cost

Owner's costs, as defined in Appendix A, are estimated as a percentage of the total facility cost.

Costs Not Included

The estimate generally excludes the following classifications:

- Escalation of costs beyond mid-1976

- Process and patent royalties

- General research and development costs

- Costs incurred beyond those that reflect the current degree of involvement in securing approvals from regulatory agencies monitoring environmental and safety considerations

- Costs generated directly by any governing or regulatory agency for administration, engineering, procurement and construction

- Sales/use tax

- Nuclear hazards insurance that may be required if nuclear hazards exist onsite before completion of project

- Housing for construction workers. 


\section{OVERALL FACILITY COST ESTIMATES}

In those cases where capital costs are expected to be invariant over alternative environmental control technologies, only order-of-magnitude cost estimates are needed. Thus average costs based on recent industrial experience or design studies were used for these fixed capital costs. A literature search and recent industrial experience for similar facilities yielded either total or unit capital costs for specific facilities. These costs were then adjusted as appropriate for differences in facility size or design.

\section{DETAILED SYSTEM COST ESTIMATES}

In those cases where the capital costs were expected to vary during comparisons of environmental control methods, commonly used procedures for estimating capital costs were used. First, the components of the system were designed in sufficient detail that basic construction activities, such as installation of specific components or of structures for which standard unit costs were available, could be determined. After direct construction costs were estimated for each such component, the costs were summed to obtain a total direct construction cost (accounts 20 to 26 of NUS-531). The indirect construction costs (accounts 91 to 94 of NUS-531) then were estimated by multiplying direct costs by indirect costs allocation percentages based on the subcontractor's experience. Table 2 shows a sample capital cost estimate for a 1200-MWe LWR plant.

\section{OPERATING COST ESTIMATES}

The operating costs are defined as all costs other than capital costs, nuclear fuel material costs, and costs included in the annual return on capital. The annual operating costs were divided into nine general categories as listed in Table 3. The costs for each of these categories were determined as described in the following sections. All operating cost estimates were based on the following assumptions: 
TABLE 2. 1200-MWe LWR Plant Capital Cost Estimate:

Sample Format

\begin{tabular}{|c|c|c|c|c|c|}
\hline \multirow[b]{2}{*}{ Cost Element } & \multicolumn{2}{|c|}{$\begin{array}{l}\text { Manhours } \\
(1,000 \mathrm{~s})\end{array}$} & \multicolumn{3}{|c|}{$\begin{array}{l}\text { Dollars } \\
(1.000 \mathrm{~s})\end{array}$} \\
\hline & Nonmanual & Manua & Material & Labor & Total \\
\hline Major Equipment & & 800 & 180,000 & 10,000 & 190,000 \\
\hline Buildings \& Structures & & 3,600 & 50,000 & 45,000 & 95,000 \\
\hline Bulk Materials & & 3,200 & 50,000 & 40,000 & 90,000 \\
\hline Site Improvements & & 400 & 10,000 & 5,000 & 15,000 \\
\hline $\begin{array}{l}\text { Direct Site } \\
\text { Construction Costs }\end{array}$ & & 8,000 & 290,000 & 100,000 & 390,000 \\
\hline $\begin{array}{l}\text { Indirect Site } \\
\text { Construction Costs }\end{array}$ & 3,000 & 2,000 & 35,000 & 60,000 & 95,000 \\
\hline Total Field Cost & 3,000 & 10,000 & 325,000 & 160,000 & 485,000 \\
\hline A-E Services & & & & & 75,000 \\
\hline Subtotal & & & & & 560,000 \\
\hline Owner's Cost & & & & & 240,000 \\
\hline Total Facility Cost & & & & & 800,000 \\
\hline Estimate Accuracy & ge & & & & $\pm 15 \%$ \\
\hline
\end{tabular}


TABLE 3. Operating Cost Estimate Worksheet

System

Author

System Description Date

Estimate Date

Important Specific Assumptions:

Cost Item

Basis and Calculations

Annual Cost

1. Personne1

2. Miscellaneous Supplies \& Equipment

3. Maintenance Materials

4. Outside Support Services

5. Miscellaneous Direct Costs

Subtotal

6. General \& Administrative $20 \%$ of above subtotal

Other G\&A

7. Process Materials

8. Utility Costs

9. Other

Total Annual Cost 
1. A11 costs are in 1976 dollars.

2. All facilities are built for a 30-year life, if not stated otherwise in the facility description.

3. Cost estimates for specific waste treatment facilities and activities include only the incremental costs for those waste treatment facilities or activities.

4. The basic rate for general and administrative (G\&A) costs is $20 \%$ of the base salary costs for personnel, supplies, equipment, outside support service and miscellaneous expenses. Other G\&A costs may be added to this base if unique costs are necessary (special insurance, etc.). This rate is based on information in NUS-531 and adjusted for current industrial experience.

5. The following items are not included in 0\&M costs because they are included in the return on capital rate:

- Unusual maintenance

- Income taxes

- Property taxes

- Insurance

- Profits

- Interest on bonds

- Depreciation

6. Unless otherwise stated, plant factors used to determine material, labor, and utility costs are $70 \%$ for reactors, $90 \%$ for reprocessing plants, and 100\% for waste treatment systems.

7. Cooling water is assumed to cost $\$ 25 / 10^{6}$ gallons.

8. Process water is assumed to cost $\$ 35 / 10^{6}$ gallons.

9. Process steam is assumed to cost $\$ 1.50 / 10001 b^{3}$.

10. Electricity is assumed to cost $\$ 0.02 / \mathrm{kW}=\mathrm{hr}$.

11. Natural gas is assumed to cost $\$ 1.50 / 1000 \mathrm{ft}^{3}$. 
12. No direct taxes are paid on waste treatment operations.

13. If maintenance staff is not known, the annual cost is assumed to be $2 \%$ of the capital cost for labor and $2 \%$ of the capital cost for materials plus the cost of any known above-normal maintenance. (One can also use $1 \% / y r$ for low maintenance items like pipes and tanks and up to $5 \%$ for high maintenance items like pumps and instruments.)

14. Cost estimates for treatment systems should include all costs from the time the effluent stream is received until the wastes are disposed.

15. Cost estimates for interim storage include only the storage costs.

16. A11 costs are for 1 year (or the amounts paid during each year).

17. Transportation and burial costs for non-high-level wastes are presented in Appendix B.

PERSONNEL COSTS

The personnel costs were estimated by multiplying the number of personnel, obtained from the facility descriptions, by the annual cost per person. The costs per person were obtained from Table 4, which is based on the 1976 Hanford, Washington labor costs for specific types of craftsmen and operators. (The labor rates in Washington are essentially the same as the rates in the U. S. Midwest region and can be considered representative of that region.)

In those cases where labor requirements for a facility are less than one person per shift, we assume the addition of personnel to perform that amount of work and a corresponding additional labor cost.

\section{MISCELLANEOUS SUPPLIES AND EQUIPMENT}

The miscellaneous supplies and equipment are the multitude of small volume materials used by the operating personnel in support of the plant operation. It excludes maintenance materials and process materials (which are defined as any materials that become part of the final product), but 
TABLE 4. Salary Schedule for Facility Personnel

Staff Position Title

Superintendent's Office

Plant Superintendent

Assistant Superintendent

Secretary

Operations

Operations Supervisor

Shift Supervisor

Senior Control Room or Chief Operator

Process or Power Operator

Equipment Operator

Equipment Attendant

Maintenance

Maintenance Supervisor

Foreman

Craftsman

Helpers

Technical

Technical Supervisor

Plant Engineer

Instrument Engineer

Nuclear Engineer

Health Physicist

Chemist

Lab and Instrument Technicians

Clerical and Services

Clerical and Services Supervisor

Typist

Storekeeper

Clerk

Yardman

Janitor

Handyman

Guard
Annual Salary/Wages

$\$ 35,000$

29,000

10,000

25,400

20,500

16,200

15,000

14,600

14,200

27,300

18,700

15,800

13,500

28,300

25,400

26,300

27,300

25,400

25,400

15,200

16,200

9,000

11,700

11,700

11,100

10,200

10,500

11,100 
includes all other materials. Typical miscellaneous supplies and equipment are ion-exchange resins, water treatment chemicals, drums and casks for disposal of wastes, and cover gases. The total miscellaneous supplies and equipment costs were obtained by estimating the costs for the two major categories of such costs: 1) the known major costs and 2) the miscellaneous unknown costs. The known major costs were developed by analyzing the facility operations to determine the operational activities, and then determining the types and quantities of materials used during those operations. The unit costs used for the materials were current industrial prices.

The miscellaneous unknown costs were obtained by comparing the operation of the specific facility to the operation of other industrial facilities and assuming that operations of similar complexity would have similar miscellaneous costs. In the absence of information from similar facilities, we assumed a cost of $\$ 2,000 / \mathrm{yr}$ for each $\$ 1,000,000$ of capital cost for a facility, based on the information in NUS-531 (pages 4-14) for typical nuclear power plants.

\section{MAINTENANCE MATERIALS}

This category includes the costs of all materials used for maintenance of the facility, of which there are two categories: 1) known major materials and 2) miscellaneous materials. The known major materials were identified by analyzing the facility design to determine those major items of equipment needing periodic replacement. The frequency of replacements was estimated; the unit costs for the equipment items were obtained by discussions with appropriate vendors and suppliers; and the average annual cost was obtained by dividing the periodic replacement costs by the replacement interval.

The miscellaneous materials (e.g., tools, wire, boards) costs were estimated by assuming that the annual costs are equal to $2 \%$ of the capital costs of those items expected to require maintenance. (Typical items not expected to require maintenance are building structures and piping systems with low corrosion rates.) 


\section{OUTSIDE SUPPORT SERVICES}

This category includes any purchased services or services obtained from outside the normal plant force. Typical examples are film badge processing, analytical work, maintenance services, overtime work by plant personnel, laundry, consultants, etc. These costs are of two types: 1) known support services and 2) miscellaneous unknown costs. The facility operation was studied to identify known support services. We then estimated the resultant costs using standard procedures for estimating activities.* The miscellaneous unknown costs were assumed to equal $\$ 700$ per year per $\$ 1,000,000$ of capital costs, based on the information in NUS-531 (pages 4-14) for typical nuclear power plants.

\section{MISCELLANEOUS DIRECT COSTS}

Numerous costs associated with a facility are difficult to categorize and individualiy are not large. Typical examples are staff training, travel expenses, rents, office supplies, vehicle operation insurance, etc. It was assumed that the annual miscellaneous costs are $\$ 400$ per million dollars of facility capital cost, based on the information in NUS-531 (pages 4-14) for typical nuclear power plants.

\section{GENERAL \& ADMINISTRATIVE COSTS}

The G\&A costs include such items as fringe benefits on salaries, purchasing and stores costs, and administrative tasks such as payroll activities. Based on typical industrial experience, this cost is assumed to be $20 \%$ of the personnel, miscellaneous supplies and equipment, maintenance

* The operation was studied to determine the activities necessary for accomplishing objectives. Each of these activities then was analyzed to determine which would be performed by plant employees and which could be better performed by outside experts. Those done by outside experts were estimated with known unit costs or by determining the work components and the costs of those components. 
materials, outside support services, and miscellaneous direct costs. In addition, any large, identifiable unusual G\&A costs, such as nuclear liability insurance, are estimated as a separate cost.

\section{PROCESS MATERIALS}

Process materials are defined as any material used during the operation that becomes a part of the final product; for example, cladding materials for fuel elements. The process material costs were determined by studying the operation and determining the types and quantities of process materials used, the unit costs of these materials (current market prices), and then multiplying the quantities used by the unit costs to obtain the total costs.

\section{UTILITY COSTS}

Utilities consist of water, steam, compressed air, electricity, and other sources of energy supplied to an operation from an off-plant source or from a central source on the plant. The consumption rates were obtained from the descriptions of the facilities or by analysis of the operations. The assumed unit costs for the utilities are presented in the list of assumptions for operating cost estimates. These unit costs are based on current industrial prices in the Midwest for purchased utilities (electricity, gas, etc.) or on typical system designs for utilities provided by plant facilities (water, steam, etc.).

\section{OTHER COSTS}

This category includes any costs that do not fit into any other category. The method of calculation depends on the nature of the cost. 

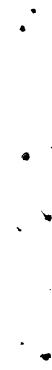
APPENDIX A

CAPITAL COST ESTIMATE DEFINITIONS 
$\therefore$

, 
APPENDIX A

CAPITAL COST ESTIMATE DEFINITIONS

The cost estimates for facilities use terms and phrases which may be unique or may differ from definitions used elsewhere. For this reason, the terms are defined below:

\section{Allowance Item}

A number arrived at by judgment used for installation or service manhours or for material or equipment cost of an item whose value is otherwise indeterminate because of the absence of design definition.

\section{A-E Services}

Services of the architect-engineer to manage the project and to engineer, design and procure all plant systems, buildings and structures and site improvements as defined in the facility and system description documents for each facility. These services include:

Management Services: Provision of essential project services such as managing construction, planning the project, scheduling, supervising and developing an estimate, project budget, project control procedures and implementation of project forecasting procedures.

Engineering: Engineering and drafting including design analyses, and the preparation of equipment specifications, design drawings, and engineering input to the ER, PSAR and FSAR. Prestartup checkout is also included.

Procurement: Procurement of equipment and materials for the plant and site facilities including solicitation of bids, equipment and material purchasing, inspection, quality assurance implementation, and shipment to the jobsite.

\section{Buildings and Structures}

Includes all materials, equipment and labor required to construct the architectural and structural components of buildings and structures including excavation and backfill, painting and coatings, heating ventilation and air conditioning service, and normal building utilities to a point $5 \mathrm{ft}$ outside the building or structure line. 
Major process equipment and associated piping, electrical, instrumentation, and site improvements are not included in this cost category.

\section{Bulk Materials}

Materials such as instruments and controls, pipe, valves, pipe fittings, pipe coverings, conduit, wire, cable, cable trays, etc., that are associated with major process equipment and that are purchased in quantity for fabrication or assembly and installation at the jobsite. Generally interpreted to mean all materials that are not defined as major equipment, buildings and structures, and site improvements.

\section{Direct Site Construction Cost}

The aggregate cost of all materials, equipment and improvements forming a permanent part of either the entire constructed project or individual facilities and of all contractor's labor expended in erecting or installing such materials and equipment or in performing such improvements.

\section{Estimate Accuracy Range}

The limits within which the cost estimate should be contained based on the facilities description and on the stated assumptions. These limits are such that there is high probability of the estimate being within this range.

\section{Estimate Assumptions}

Suppositions, frequently expressed quantitatively, that are agreed to by the interested parties as the basis for estimate preparation.

\section{Indirect Site Construction Cost}

Material and labor costs that cannot be identified with specific direct cost operations in the construction of either the entire project or individual facilities. These supportive service costs apply in such a manner to several direct operations that a separate allocation to each operation cannot meaningfully be made. Examples are contractor's supervision, construction tools, equipment and consumables, temporary construction facilities and utilities, material handling, cleanup and the like. Contractor's fee is also included. These costs are combined and expressed as a factor of direct labor in each facility estimate.

Labor

Al1 manual and nonmanual personnel that are directly hired by the contractor for performing the work at the project site. 


\section{Major Equipment}

A11 purchased equipment that does not require or involve third party labor at the construction site for installation or erection.

Types of major equipment include pressure vessels, heat exchangers, cooling towers, tanks, boilers, pumps and drivers, vacuum equipment, compressors and drivers, materials handling equipment, slave manipulators and other equipment.

\section{Manhour}

Classically, a unit of measurement equal to one hour of work by one man. Manhours are further classified in the specific categories indicated below.

A-E Nonmanual Manhours: A11 manhours expended by the A-E salaried personnel in the performance of the work and who are assigned to the A-E permanent office.

Indirect Site Nonmanual Mahours: A11 manhours spent in the performance of the work at the construction site office by contractor's salaried personnel whose responsibilities include supervising construction, site engineering, site procurement and other construction support services.

Site Manual Manhours: A11 manhours (direct and indirect) expended by skilled and unskilled craftsmen, including craft supervision through general foreman, whose compensation is normally based on hourly wages and who are on the contractor's payroll.

Total Facility Manhours: The sum of all manual and nonmanual manhours on the project including those hours that could later be converted to construction subcontracts (See Subcontracts).

\section{Mid-1976 Costs}

Dollar amounts stated in values that have been adjusted for changes in the purchasing power of the dollar at mid-1976.

\section{Offsite}

Beyond the boundary line marking the limits of plant property.

Onsite

Within the boundary line marking the limits of plant property. 
Owner Costs

Al1 costs incurred by the owner within his own organization in connection with the facility which normally do not form a part of the A-E or contractor scope of work. Examples are:

- Land acquisition

- Equipment spares not permanently installed in the plant

- Permits and licenses

- Interest during construction

- Startup

- Catalysts, chemicals and other initial inventories including furnishings, tools and maintenance equipment

- Owner's engineering, operating and accounting activities

- Protective clothing and personnel dosimeters

- Spare parts and warehouse stock

- Operating procedures and manuals

- Insurance

\section{Price Index}

A statistical measure that relates material and equipment prices in a given time period to those of a specified base period. A price index includes all direct and indirect costs plus any markup or profit. Price indices are published at regular intervals.

\section{Scope}

Description of the type of work within the A-E's contractor's and owner's responsibility; for example, construction, engineering, procurement, management, etc. Also refers to the description and definition of the process, design details, capacities, physical sizes, and so on required for translation to the cost estimate.

Site Improvements

Those items of work within the limits of plant property that are not identified with major equipment, buildings and structures, bulk construction materials or temporary construction facilities. Examples of the kinds of 
work in this category include site clearing and grubbing, site grading, roads, railroads, walks, fences, area lighting, paving, sewers and fire water system (external to buildings), reservoirs and ponds, and 1 andscaping.

\section{Site-Related}

A11 facilities, the design and extent of which are essentially unique to a given site. The term "site-sensitive" is also used in this context.

\section{Startup}

The tasks performed during the period between mechanical completion and commercial operation at which time the project is operationally checked out. This function is included in owner's costs.

\section{Subcontracts}

Specialized items of work or special equipment that require a contract with a third party to provide materials, equipment, labor and/or engineering services to perform a portion of the facilities' scope of work. Subcontracts may also include specialty process units or sections thereof. For purposes of the current estimates, subcontract costs and manhours are apportioned between material/equipment and labor.

\section{Takeoff}

The measurement or survey of physical quantities of materials required for the facility through the use of drawings or sketches.

\section{Total Field Cost}

The sum of the Direct Site Construction Cost and the Indirect Site Construction cost.

\section{Total Facility Cost}

The total of all costs assignable to each facility or to the entire project and generated by the A-E, contractor, owner and/or owner's agent in discharging their individual responsibilities to engineer, procure, construct and start up the project.

Wage Rate

Compensation based on hourly wages, including payroll additives and fringe benefits expressed as dollars per hours, and paid to craftsmen, both skilled and unskilled, and craft supervision, through general foreman, who are engaged in the construction and who are on the contractor's payroll. 

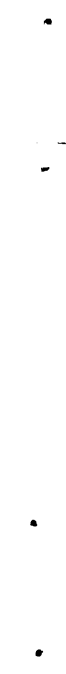
APPENDIX B

COSTS OF TRUCK SHIPMENT OF NON-HIGH-LEVEL WASTE 
$\because$ 


\section{APPENDIX B}

\section{COSTS OF TRUCK SHIPMENT OF NON-HIGH-LEVEL WASTE}

Table B. 1 provides estimates of the costs of truck shipment of solidified non-high-level waste from reactor sites to commercial burial grounds. Cost estimates are based on the following assumptions:

1. The waste container is a DOT Specification 17C 55-gallon steel drum. Fill volume is assumed to be $7.0 \mathrm{ft}^{3}$ per drum (approximately $90 \% \mathrm{fi11}$ ).

2. The shipment distance from reactor site to commercial burial ground is assumed to be 500 miles. (1)

3. The number of drums per shipment and the amount of shielding required depends on the dose rate at the surface of a 55-gallon drum. The shipment and shielding modes assumed for this study are shown in Table B.2.

4. Cost of a 55-galion drum is assumed to be $\$ 20$.

5. Labor costs are based on $\$ 10.00$ per man-hour. Assume 1 man-hour to fi11 and load a drum into a van (2 men at 30 minutes each man). Assume 2 man-hours to fill and load a drum into a cask.

6. Waste immobilization is assumed to be by incorporation of the waste in cement using a mixture of 1 part cement with 1 part waste by volume. The assumed cost of cement is $\$ 1.50$ per cubic foot.

7. Cask rental charges are assessed as follows: (1)

$$
\begin{aligned}
\text { Shielded van } & =\$ 50.00 / \text { day } \\
14-\text { drum cask } & =\$ 100.00 / \text { day } \\
6 \text {-drum cask } & =\$ 200.00 / \text { day }
\end{aligned}
$$

A round trip is assumed to require four days for completion, including cask loading and unloading times.

8. Hauling charges are calculated on the basis of $\$ 1.30 / \mathrm{mile}$, one-way, and $\$ 2.20 /$ mile, round trip. (2) The unshielded van is charged the oneway tariff. The shielded van and the casks are charged the round trip tariff multiplied by the one-way mileage.

9. Burial fees at commercial burial grounds are based on drum surface dose rates. The assumed burial fee schedule is as follows:*

*Direct inquiries were made of commercial burial ground operations to obtain estimates of burial fees and cask handling charges. Assumptions about these costs are based on responses to inquiries. 


\begin{tabular}{ccc} 
Surface Dose Rate & Burial Fee \\
\cline { 3 - 3 }$<200 \mathrm{mR} / \mathrm{hr}$ & & $\$ 2.00 / \mathrm{ft}^{3}$ \\
$200 \mathrm{mR} / \mathrm{hr}-1 \mathrm{R} / \mathrm{hr}$ & & $\$ 2.75 / \mathrm{ft}^{3}$ \\
$1 \mathrm{R} / \mathrm{hr}-10 \mathrm{R} / \mathrm{hr}$ & $\$ 4.00 / \mathrm{ft}^{3}$ \\
$>10 \mathrm{R} / \mathrm{hr}$ & $\$ 10.00 \mathrm{ft}^{3}$
\end{tabular}

10. The cask handling charge is assumed to be $\$ 200$ per cask*

TABLE B.1 Disposal Costs Using 55-gallon Drums

\begin{tabular}{|c|c|c|c|c|}
\hline & $\begin{array}{l}55 \text {-gal } \\
\text { Drums in } \\
\text { Unshielded } \\
\text { Van } \\
\end{array}$ & $\begin{array}{l}55 \text {-gal } \\
\text { Drums in } \\
\text { Shielded } \\
\text { Van } \\
\end{array}$ & $\begin{array}{l}55 \text {-gal } \\
\text { Drums in } \\
14 \text {-Drum } \\
\text { Cask } \\
\end{array}$ & $\begin{array}{l}55-\text { gal } \\
\text { Drums in } \\
6 \text {-Drum } \\
\text { Cask } \\
\end{array}$ \\
\hline Number of Drums per Shipment & 66 & 33 & 14 & 6 \\
\hline $\begin{array}{l}\text { Cubic Feet of Waste per Shipment } \\
\text { Packaging Costs }\left(\$ / f t^{3}\right)\end{array}$ & 462 & 231 & 98 & 42 \\
\hline Containers & 2.86 & 2.86 & 2.86 & 2.86 \\
\hline Labor & 1.43 & 1.43 & 2.86 & 2.86 \\
\hline Solidification & 0.75 & 0.75 & 0.75 & 0.75 \\
\hline \multicolumn{5}{|l|}{ Transportation Costs $\left(\$ / \mathrm{ft}^{3}\right)$. } \\
\hline Cask Rental & -- & 0.86 & 4.08 & 19.04 \\
\hline Hauling Charge & 1.41 & 4.76 & 11.22 & 26.19 \\
\hline \multicolumn{5}{|l|}{ Disposal Costs $\left(\$ / \mathrm{ft}^{3}\right)$} \\
\hline Burial Fee & 2.00 & 2.75 & 4.00 & 10.00 \\
\hline Cask Handling Charge & -- & -- & 2.04 & 4.76 \\
\hline Total Cost $\left(\$ / f t^{3}\right)$ & 8.45 & 13.41 & 27.81 & 66.46 \\
\hline Total Cost ( $\$ /$ shipment) & 3903.90 & 3097.71 & 2725.38 & 2791.32 \\
\hline
\end{tabular}


TABLE B.2 Reference Shipment Modes for 55-Galion Drums

$\begin{array}{lcl}\begin{array}{c}\text { Drum Surface } \\ \text { Dose Rate }\end{array} & \begin{array}{c}\text { No. of Drums } \\ \text { Per Shipment }\end{array} & \frac{\text { Mode of Shipment }}{\text { Unshielded sole-use van }} \\ 200 \mathrm{mR} / \mathrm{hr} & 33 & \begin{array}{l}\text { Shielded van ( } 1 \text { inch } \\ \text { lead equivalent) }\end{array} \\ 1 \mathrm{RR} / \mathrm{hr}-10 \mathrm{R} / \mathrm{hr} & 14 & \begin{array}{l}\text { Cask }(22.5 \text { inch lead } \\ \text { equivalent) }\end{array} \\ >10 \mathrm{R} / \mathrm{hr} & 6 & \begin{array}{l}\text { Cask ( } 5.0 \text { inch lead } \\ \text { equivalent) }\end{array}\end{array}$

$\underline{\text { References }}$

1. The Environmental Impact of Transportation of Nuclear Materials in the LMFBR Program, ERDA-40, USERDA, Washington, D.C., May 1975.

2. Tri-State Motor Transit Company, Local Commodity Tariff No. 1045-D, Mileage Truckload Commodity Rates Applying on Radioactive Material and Empty Containers for Radioactive Materials, Effective April 30, 1976. 
- 
1. The Environmental Impact of Transportation of Nuclear Materials in the LMFBR Program, ERDA-40, May 1975.

2. Evaluation of Routine Exposure from the Shipment of Radioactive Material for the Nuclear Power Industry, NSS-8172.2, Holmes and Narver, Inc., Anaheim, CA, September 1974.

3. Mullarkey, T. B. et al., A Survey and Evaluation of Handling and Disposing of Solid Low-Level and Transuranium Contaminated Nuclear Fuel Cycle Wastes, NUS Corporation, Rockvi11e, MD, August 1976 (Draft).

4. Tri-State Motor Transit Company, Local Commodity Tariff No. 1045-D, Mileage Truckload Commodity Rates Applying on Radioactive Material and Empty Containers for Radioactive Materials, Effective April 30, 1976, p. 46. 
BNWLL -2210

$U C-11$

\section{DISTRIBUTION}

No. of

Copies

\section{OFFSITE}

1 A. A. Churm ERDA Chicago Patent Group U.S. Energy Research and Development Administration Argonne, IL 60439

27 ERDA Technical Information Center

H. Glauberman

Division of Environmental

Control Technology

Germantown, MD 20767

A. F. Kluk

Division of Environmental

Control Technology

Germantown, MD 20767

J. L. Liverman

Office for the Assistant

Administrator of Environment

and Safety

Germantown, MD 20767

W. E. Mott

Division of Environmental

Control Technology

Germantown, MD 20767
No. of

Copies

ONSITE

1 ERDA Richland Operations Office H. Ransom

38 Battelle-Northwest

N. E. Carter

L. L. Clark

B. M. Cole

R. M. Fleischman

J. Goodenough

C. M. Heeb

T. J. Kabele (5)

R. C. Liikala

K. J. Schneider

J. C. Schuette

J. R. Young (20)

Technical Information Files (3)

Technical Publications (1) 


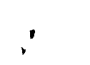

.

$\therefore$

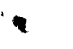

